\title{
PENGARUH CSR TERHADAP NILAI PERUSAHAAN DENGAN GCG SEBAGAI PEMODERASI
}

\section{CSR INFLUENCE ON CORPORATE VALUE WITH GCG AS MODERATORS}

\author{
Desita Riyanta Mitra Karina ${ }^{1}$, Iwan Setiadi ${ }^{2}$ \\ ${ }_{1.2}^{12}$ Institute Teknologi dan Bisnis Ahmad Dahlan Jakarta \\ 12desitariyanta@gmail.com
}

\begin{abstract}
Abstrak
Tujuan penelitian ini adalah menganalisis bagaimana pengaruh Corporate Social Responsibility terhadap nilai perusahaan. Kedua, mengetahui apakah Good Corporate Governance memoderasi hubungan antara Corporate Social Responsibility dengan nilai perusahaan. Penentuan sampel dilakukan menggunakan metode purposive sampling, yaitu teknik sampling dengan menggunakan pertimbangan dan batasan tertentu sehingga sampel yang dipilih relevan dengan tujuan penelitian. Jumlah sampel yang diperoleh sebanyak 12 perusahaan yang terdaftar di IICG. Data dianalisis dengan analisis deskriptif dan analisis regresi berganda. Hasil analisis menunjukkan bahwa Corporate Social Responsibility secara signifikan berpengaruh positif terhadap nilai perusahaan. Hal ini berarti semakin baik penerapan CSR oleh perusahaan maka nilai perusahaan akan semakin meningkat. Kedua, Good Corporate Governance sebagai variabel moderating memperlemah terhadap hubungan antara Corporate Social Responsibility dan nilai perusahaan.
\end{abstract}

Kata Kunci: Corporate Social Responsibility, Nilai Perusahaan, Good Corporate Governance

\begin{abstract}
The purpose of this study is to analyze how the influence of Corporate Social Responsibility on company value. Second, find out whether Good Corporate Governance moderates the relationship between Corporate Social Responsibility and corporate value. Determination of the sample is done using the purposive sampling method, which is a sampling technique using certain considerations and limitations so that the selected sample is relevant to the purpose of the study. The number of samples obtained were 12 companies registered with IICG. Data were analyzed by descriptive analysis and multiple regression analysis. The analysis shows that Corporate Social Responsibility has a significant positive effect on firm value. This means that the better the implementation of CSR by companies, the value of the company will increase. Second, Good Corporate Governance as a moderating variable weakens the relationship between Corporate Social Responsibility and corporate value.
\end{abstract}

Keywords: Corporate Social Responsibility, Corparation Value, Good Corporate Governance

\section{PENDAHULUAN}

Peningkatan nilai perusahaan yang tinggi merupakan tujuan jangka panjang yang seharusnya di capai perusahaan yang akan tercermin dari harga pasar saham karena penilaian investor terhadap perusahaan dapat diamati melalui pergerakan harga saham (Retno dan Priantinah, 2012). Menurut Sobirin (1999) dalam Katiya dan Agus (2011) agar suatu bisnis bisa bertaham maka suatu perusahaan harus merubah kontrak sosialnya dengan memposisikan bisnis sebagai bagian dari sistem sosial dan politik yang ada. Jika perusahaan lebih responsive terhadap tuntutan masyarakat maka kegiatan bisnis lebih bisa di terima masyarakat. Melaksanakan CSR dalam jangka panjang akan menumbuhkan rasa penerimaan masyarakat terhadap kehadiran perusahaan yang dapat memberikan keuntungan ekonomi berupa peningkatan nilai perusahaan.

Implementasi GCG di Indonesia sampai saat ini masih belum memenuhi harapan semua pihak. GCG semakin penting dalam dalam praktik bisnis di Indonesia. Oleh karena itu penerapan GCG memerlukan komitmen yang kuat untuk mewujudkannya. Penerapan GCG sangat diperhatikan investor dalam melakukan keputusan investasi. Adanya GCG akan meyakinkan investor bahwa 
perusahaan telah dikelola dengan baik oleh manajemen untuk kelangsungan hidup perusahaan dan juga untuk kelangsungan hidup perusahaan dan juga untuk kepentingan para pemegang sahamnya.

Pengungkapan CSR merupakan hal penting bagi perusahaan, karena CSR adalah bentuk tanggung jawab meningkatkan citra perusahaan, kegiatan CSR juga dapat digunakan sebagai salah satu keunggulan kompetitif perusahaan yang dapat meningkatkan penjualan karena dapat menarik konsumen. Terwujudnya praktek CSR dan GCG dalam suatu perusahaan maka outcomes dari praktek tersebut akan mempengaruhi nilai perusahan.

Merosotnya nilai saham PT. Garuda Indonesia (Persero) yang merupakan perusahaan yang masuk dalam pemeringkatan CGPI (Corporate Governance Perception Index). Harga saham PT Garuda Indonesia (Persero) Tbk anjlok 4,4 persen pada penutupan perdagangan sesi pertama, Kamis (25/4) siang. Alhasil, harga saham maskapai penerbangan pelat merah ini bertengger di level Rp 478 per saham dari sebelumnya di area Rp 500 per saham. Mengutip RTI Infokom, harga saham emiten berkode GIAA ini bergerak dalam rentang Rp 474 per saham sampai Rp 500 per saham sejak pembukaan tadi pagi hingga pukul 12.00 WIB. Volume transaksinya sendiri sebanyak 28,64 juta kali. Analis Oso Sekuritas Sukarno Alatas mengatakan kondisi ini terjadi karena polemik yang terjadi di tubuh perusahaan. Dua komisaris tak sependapat dengan manajemen dalam membukukan laporan keuangan sepanjang 2018. Pelaku pasar merespons negatif terhadap dua pendapat yang berbeda tersebut. (cnnindonesia.com,2019).

Nilai perusahaan (Value Brand) memegang peranan penting perusahaan, karena dapat membentuk kinerja dalam upaya menumbuhkan keyakinan terhadap pengguna informasi dan masyarakat yang berkepentingan. Perusahaan yang baik tercermin pada Value brand itu sendiri begitu juga sebaliknya, karena dengan nilai perusahaan yang tinggi akan diikuti pula oleh tingginya kemakmuran pemegang saham (Bringham Gapensi, 1996 dalam Dewi Winarti, 2012).

Beberapa penelitian terdahulu banyak yang menghubungkan mengenai pengaruh Corporate Social Responsibility terhadap Nilai Perusahaan menunjukkan hasil yang berbeda-beda. Penelitian yang dilakukan oleh Reny dan Denies (2012), menunjukkan GCG berpengaruh positif terhadap nilai perusahaan, pengungkapan CSR tidak berpengaruh terhadap nilai perusahaan, GCG dan pengungkapan CSR berpengaruh positif terhadap nilai perusahaan. Junda (2018), dengan hasil CSR berpengaruh positif signifikan terhadap nilai perusahaan. I Putu Indra Wijaya dan Ni Gusti Putu wirawati (2019) dengan hasil CSR berpengaruh positif pada nilai perusahaan, GCG mampu memperkuat pengaruh CSR pada nilai perusahaan. Tria, Nila dan Ferina (2018), dengan hasil GCG berpengaruh terhadap nilai perusahaan. Dyah (2012), dengan hasil CSR dan GCG berpengaruh positif terhadap nilai perusahaan.

Adapun perbedaan penelitian ini dengan penelitian - penelitian sebelumnya adalah peneliti ini menggunakan variabel GCG sebagai moderasi selain itu peneliti ini juga menggunakan price earning ratio (PER) untuk mengukur nilai perusahaan. Penelitian ini menggunakan skor CGPI dalam variabel GCG karena dalam melakukan kegiatan pemeringkatan CGPI, IICG menggunakan empat aspek penilaian yang terdiri dari self assessment, kelengkapan dokumen, penyusunan paper atau makalah serta observasi langsung ke perusahaan yang akan dinilai. Peneliti menggunakan tahun penelitian sampai dengan tahun 2017 dikarenakan laporan CGPI untuk tahun selanjutnya masih dalam proses penilaian.

\section{Pengaruh CSR terhadap Nilai Perusahaan}

Menurut Hamdani (2016:174) corporate social responsibility (CSR) didefinisikan sebagai tanggung jawab moral suatu perusahaan kepada para stakeholdernya, terutama komunitas atau masyarakat di sekitar wilayah kerja dan operasinya. Suatu perusahaan dapat dikatakan bertanggung jawab secara sosial, apabila memiliki visi atas kinerja operasional yang tidak hanya merealisasikan profit, akan tetapi dapat meningkatkan kesejahteraan masyarakat atau lingkungan sosialnya. Tanggungjawab sosial perusahaan merupakan program yang memberikan nilai tambah bagi semua stakeholder, termasuk meningkatkan kinerja dan nilai tambah perusahaan secara jangka panjang. Hasil penelitian Armi Sulton, Ni Ketut Suransi dan Alamsyah (2016) menemukan bahwa CSR berpengaruh terhadap nilai perusahaan. Hal ini sejalan dengan paradigma yang menyatakan bahwa stabilitas dan kemakmuran ekonomi jangka panjang hanya dapat dicapai jika perusahaan melakukan 
tanggung jawab sosial kepada masyarakat (Hartianti, 2006 dalam Armi Sulton, Ni Ketut Suransi dan Alamsyah, 2016).

H1: Corporate Social Responsibility berpengaruh positif signifikan terhadap nilai perusahaan.

\section{GCG Memoderasi Hubungan CSR Dengan Nilai Perusahaan}

Implementasi CSR merupakan salah satu wujud pelaksanaan prinsip GCG. Good corporate governance (GCG) dan corporate social responsibility (CSR) adalah satu kesatuan yang tidak dapat dipisahkan. Keduanya memiliki kedudukan penting dalam praktik bisnis dan saling berhubungan satu sama lain. Salah satu prinsip pelaksanaan GCG adalah responsibility, prinsip ini sebagai bentuk tanggung jawab sosial yang berorientasi kepada stakeholders.

Namun pemeringkatan CGPI di Indonesia masih bersifat voluntary (sukarela) dan tidak diwajibkan sehingga perusahaan yang ikut dalam pemeringkatan CGPI setiap tahunnya tidak sama dan hanya sebagian kecil dari keseluruhan perusahaan (hanya beberapa perusahaan yang ikut berturut-turut setiap tahunnya). Hal ini menyebabkan pasar kurang yakin dengan hasil pemeringkatan CGPI, apalagi belum ada dampak yang signifikan terhadap CSR jika dibandingkan dengan perusahaan yang tidak mengikuti pemeringikatan CGPI.

Penelitian tentang pengungkapan tanggungjawab sosial dikaitkan dengan good corporate governance, sebelumnya telah dilakukan Winda Heldayati, (2014) dengan hasil penelitian yang menunjukkan bahwa tidak adanya pengaruh pengungkapan Corporate Social Responsibility (CSR) terhadap nilai perusahaan dengan mekanisme Good Corporate Governance sebagai variabel moderasi. Berdasarkan penjelasan dan temuan empiris di atas, maka hipotesis kedua adalah :

$\mathrm{H} 2$ : Good Corporate Governance akan memperlemah hubungan antara Corporate Social Responsibility dengan nilai perusahaan.

\section{METODE}

Penelitian ini adalah penelitian yang bersifat pengujian hipotesis karena dari hasil analisis data akan mencari tahu penyebab atau alasan yang mempengaruhi variabel indepnden terhadap variabel dependen. Data yang digunakan dalam penelitian ini adalah laporan keuangan yang terdaftar di IICG periode 2011-2017. Data sekunder ini diperoleh dengan mengunduh pada website BEI.

\section{Definisi Operasional dan Pengukuran Variabel Nilai Perusahaan}

Nilai perusahaan dapat memberikan kemakmuran pemegang saham secara maksimum apabila harga saham perusahaan meningkat. Semakin tinggi harga saham, maka semakin tinggi kemakmuran pemegang saham. Untuk mencapai nilai perusahaan umumnya para pemodal menyerahkan pengelolaannya kepada para professional, yaitu manajer atau komisaris. Perbandingan antara harga saham perusahaan dengan keuntungan yang diperoleh oleh para pemegang saham adalah rasio yang digunakan untuk mengukur penelitian ini. Rumus PER ini telah digunakan oleh Yulia Firda (2019). Perhitungan dengan menggunakan rumus sebagai berikut :

\section{PER $=\underline{\text { Market Price Per Share }}$ Earning Per Share}

Untuk mengukur perubahan kemampuan laba yang di harapkan di masa yang akan dating merupakan salah satu fungsi Price earning ratio (PER). Semakin besar kemungkinan perusahaan untuk tumbuh sehingga dapat meningkatkan nilai perusahaan maka PER pun akan semakin besar.

\section{Corporate Social Responsibility}

Pengukuran variabel CSR menggunakan kategori pembobotan dengan metode content analysis yang mengacu pada instrument yang digunakan oleh wibisono, (2007) dalam Katiya nahda dan Agus, (2011) yang mengelompokkan informasi CSR ke dalam kategori lingkungan, energy, tenaga kerja, produk, keterlibatan masyarakat, dan umum yang terdiri dari 78 item pernyataan.

Pendekatan untuk menghitung CSR pada dasarnya menggunakan pendekatan dikotomi yaitu setiap item CSR dalam instrument penelitian diberi nilai 1 jika diungkapkan dan nilai 0 jika tidak 
diungkapkan, hal ini sebagaimana dilakukan oleh Sayekti dan Wondabio, (2007) dalam Katiya Nahda dan Agus, (2011). Untuk memperoleh keseluruhan nilai setiap perusahaan yaitu dengan cara menjumlahkan nilai dari setiap item. Rumus perhitungan CSR adalah sebagai berikut :

$$
\mathrm{CSRj}=\underline{\Sigma X \mathrm{ij}}
$$

$\mathrm{nj}$

keterangan :

CSRj : Corporate Social Responsibility index perusahaan

njq : Jumlah item untuk perusahaan

Xij $\quad$ : Dummy variabel : 1 jika item diungkapkan: 0 jika item tidak

Di ungkapkan.

\section{Good Corporate Governance}

GCG diukur dengan menggunakan instrument yang telah dikembangkan oleh IICG berupa CGPI yang berisi skor hasil survey mengenai penerapan Corporate Governance pada perusahaan yang telah terdaftar di BEI.

\section{Metode Pengumpulan Data}

Data yang dikumpulkan untuk penelitian ini adalah data sekunder yang berbentuk laporan keuangan perusahaan yang terdaftar di IICG. Data dalam penelitian ini didapatkan melalui website Bursa Efek Indonesia (www.idx.co.id) dengan mengambil data laporan keuangan (financial report) periode tahun 2011 sampai dengan 2017. Serta melakukan pengumpulan data dengan melakukan penelitian kepustakaan yang bersumber dari jurnal-jurnal ilmiah, buku-buku dan skripsi yang mempunyai hubungan erat dengan penelitian ini.

\section{Teknik Analisis Data}

Metode analisis yang digunakan dalam penelitian ini adalah metode analisis statistik dengan menggunakan SPSS 24. Penelitian ini melakukan uji asumsi klasik terlebih dahulu sebelum melakukan uji hipotesis.

\section{HASIL DAN PEMBAHASAN \\ Deskripsi Data}

Data yang dikumpulkan untuk penelitian ini adalah data sekunder yang berbentuk laporan keuangan perusahaan yang terdaftar di IICG. Data dalam penelitian ini didapatkan melalui website Bursa Efek Indonesia (www.idx.co.id) dengan mengambil data laporan keuangan (financial report) periode tahun 2011 sampai dengan 2017. Serta melakukan pengumpulan data dengan melakukan penelitian kepustakaan yang bersumber dari jurnal-jurnal ilmiah, buku-buku dan skripsi yang mempunyai hubungan erat dengan penelitian ini.

\section{Deskripsi Sampel Penelitian}

Populasi yang dijadikan sampel terdiri dari saham perusahaan yang terdaftar dalam IICG dan listing berturut-turut selama periode 2011-2017. Perusahaan yang dimaksud meliputi sektor Metal and Mineral Mining, sektor Coal Mining, sektor Building Construction, sektor Property and Real Estate, sektor Transportation, sektor Wholesale (Durable \& Non-Durable Goods), dan Sektor Tourism Restaurant and Hotel.

Berikut adalah tabel yang menjelaskan mengenai proses pemilihan sampel dalam penelitian ini :

Tabel 1. Proses Pemilihan Sampel

\begin{tabular}{cccc}
\hline No. & \multicolumn{1}{c}{$\begin{array}{c}\text { Keterangan } \\
\text { Perusahaan Sampel }\end{array}$} & $\begin{array}{c}\text { Jumlah } \\
\text { Perusahaan }\end{array}$ & $\begin{array}{c}\text { Jumlah } \\
\text { Data }\end{array}$ \\
\hline 1. & $\begin{array}{l}\text { Perusahaan yang termasuk dalam } \\
\text { pemeringkatan selama 2011-2017 }\end{array}$ & 80 & 560
\end{tabular}




\begin{tabular}{|c|c|c|c|}
\hline 2. & $\begin{array}{l}\text { Perusahaan perbankan, asuransi dan } \\
\text { finance }\end{array}$ & (34) & $(238)$ \\
\hline 3. & $\begin{array}{l}\text { Tidak ikut dalam penilaian selama } 7 \\
\text { tahun berturut-turut }\end{array}$ & (34) & (2) \\
\hline & $\begin{array}{l}\text { Jumlah sampel perusahaan yang } \\
\text { memenuhi kriteria selama periode } \\
2011-2017\end{array}$ & 12 & 84 \\
\hline
\end{tabular}

Sumber : Data Sekunder yang diolah

Berdasarkan hasil tabel 1 diatas diperoleh total awal sebanyak 80 perusahaan yang terdaftar di IICG selama periode 2011-2017. Adapun perusahaan finance, asuransi dan perbankan yang tidak masuk dalam kriteria penelitian yaitu 34 perusahaan. Serta perusahaan yang tidak terdaftar selama 7 tahun berturut-turut yaitu 34 perusahaan.

\section{Analisis Statistik Deskriptif}

Tabel 2. Hasil Analisis Statistik Deskriptif

Descriptive Statistics

\begin{tabular}{lccccc}
\hline & N & Minimum & Maximum & Mean & $\begin{array}{c}\text { Std. } \\
\text { Deviation }\end{array}$ \\
\hline $\begin{array}{l}\text { Corporate Social } \\
\text { Responsibility }\end{array}$ & 84 &, 06 & 1,10 &, 4058 &, 28686 \\
$\begin{array}{l}\text { Good Corporate } \\
\text { Governance }\end{array}$ & 84 & 8,30 & 97,17 & 80,4263 & 10,70288 \\
Price Earning Rasio & 84 & $-13,10$ & 421,47 & 26,2476 & 61,20186 \\
Ukuran Perusahaan & 84 & 13,98 & 30,52 & 21,0348 & 4,29902 \\
Return On Assets & 84 & $-64,39$ & 44,90 & 2,8631 & 13,39377 \\
Debt to Equity Rasio & 84 & $-24,12$ & 17,75 &, 5843 & 4,00482 \\
Valid N (listwise) & 84 & & & & \\
\hline
\end{tabular}

Sumber : data sekunder diolah, 2020

Tabel di atas menunjukkan jumlah sampel penelitian sebanyak 84 perusahaan. Nilai rata-rata variabel nilai perusahaan yang diproksikan dengan Price Earning Ratio (PER) adalah 26,2476 dengan standar deviasi 61,20186. Nilai minimum PER sebesar -13,10 yaitu perusahaan PT. Aneka Tambang (Persero) Tbk. pada tahun 2014. Sedangkan nilai maksimum sebesar 421,47 yaitu oleh perusahaan PT. Aneka Tambang (Persero) Tbk pada tahun 2015. CSR yang diproksikan CSR indeks mempunyai nilai rata-rata 0,4058 dengan standar deviasi 0,28686 . Nilai minimum CSR sebesar 0,06 yaitu pada perusahaan PT. Pembangunan Jaya Ancol Tbk pada tahun 2013. sedangkan nilai maksimum sebesar 1,10 yaitu pada perusahaan PT. Timah (Persero) Tbk pada Tahun 2012. GCG yang diproksikan dengan skor hasil survey mengenai penerapan GCG mempunyai nilai rata-rata 80,4263 dengan standar deviasi 10,70288. nilai Minimum GCG sebesar 8,30 yaitu pada perusahaan PT. United Tractors Tbk pada tahun 2016. Sedangkan nilai maksimum sebesar 97,17 yaitu pada perusahaan PT. Jasa Marga (Persero) Tbk pada tahun 2017. Ukuran perusahaan yang di proksikan dengan Size dapat diketahui besarnya ukuran perusahaan (Size) periode 2011-2017 berada di antara 13,98 dan 30,52. Nilai rata-rata sebesar 21,0348 dan standar deviasi sebesar 4,29902. Perusahaan dengan ukuran perusahaan (Size) terendah adalah PT. Indo Tambangraya Megah Tbk. tahun 2016 sebesar 13,98. Sedangkan ukuran perusahaan (Size) tertinggi adalah PT. Garuda Indonesia (Persero) Tbk tahun 2011 sebesar 30,52. Profitabilitas yang di proksikan dengan ROA mempunyai nilai ratarata 2,8631 dengan standar deviasi 13,39377. Nilai minimum ROA sebesar -64,39 pada perusahaan PT. Bumi Resources Tbk pada tahun 2015. Sedangkan nilai maksimum ROA sebesar 44,90 pada perusahaan PT. Garuda Indonesia (persero) Tbk pada tahun 2011. Leverage yang di proksikan dengan DER dapat diketahui besarnya leverage (DER) periode 2011-2017 berada di antara -24,12 dan 17,75. Nilai rata-rata sebesar 0,5843 dengan standar deviasi 4,00482. Perusahaan dengan 
leverage (DER) terendah adalah PT. Bumi Resources Tbk tahun 2011. Sedangkan perusahaan dengan leverage (DER) tertinggi adalah PT. Bumi Resources Tbk tahun 2012.

\section{Uji Asumsi Klasik \\ Uji Normalitas}

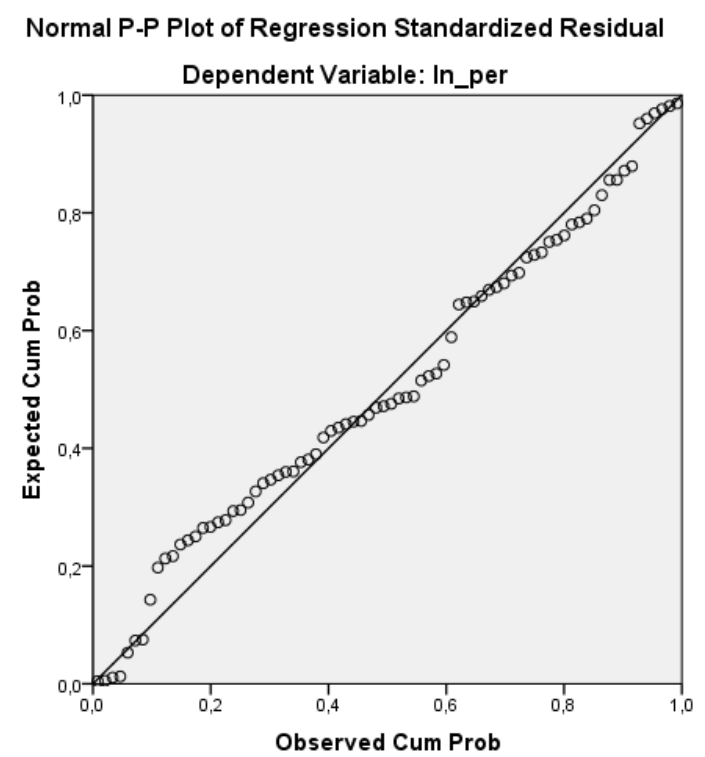

Gambar 1. Uji Normalitas

Sumber : data sekunder diolah

Berdasarkan gambar 1 di atas, dapat dilihat bahwa data menyebar disekitar garis diagonal dan mengikuti arah garis diagonal pada grafik histogram, hal ini menunjukkan bahwa pola distribusi normal. Jadi dapat disimpulkan bahwa berdasarkan grafik normal probability plot, model regresi memenuhi asumsi normalitas.

Tabel 3. Uji Kolmogorov-Smirnov One-Sample Kolmogorov-Smirnov Test

\begin{tabular}{llr}
\hline \multicolumn{2}{c}{ One-Sample Kolmogorov-Smirnov Test } \\
& \multicolumn{1}{c}{$\begin{array}{c}\text { Unstandardized } \\
\text { Residual }\end{array}$} \\
\hline $\mathrm{N}$ & & 78 \\
\hline Normal Parameters ${ }^{\mathrm{a}, \mathrm{b}}$ & Mean &, 0000000 \\
\cline { 2 - 3 } & $\begin{array}{l}\text { Std. } \\
\text { Deviation }\end{array}$ &, 95006930 \\
\hline Most Extreme & Absolute &, 093 \\
\cline { 2 - 3 } Differences & Positive &, 063 \\
\cline { 2 - 3 } & Negative &,- 093 \\
\hline Test Statistic & &, 093 \\
\hline Asymp. Sig. (2-tailed) & &, $093^{\mathrm{c}}$ \\
\hline
\end{tabular}

a. Test distribution is Normal.

b. Calculated from data.

c. Lilliefors Significance Correction.

Sumber : Data sekunder diolah 
Berdasarkan hasil uji normalitas pada table 3 di atas menunjukkan bahwa data sudah terdistribusi normal. Hal ini ditunjukkan dengan nilai Kolmogorov-smirnov 0,093 dan nilai signifikansinya 0,093 di atas 0,05 . Hal ini menunjukkan bahwa model regresi tersebut sesuai dengan asumsi normalitas. Hal ini konsisten dengan hasil uji Normal Probability plot.

\section{Uji Autokorelasi}

Tabel 4. Uji Autokorelasi

Model Summary ${ }^{b}$

\begin{tabular}{lrrrrr} 
Model & R & R Square & $\begin{array}{c}\text { Adjusted R } \\
\text { Square }\end{array}$ & $\begin{array}{c}\text { Std. Error of } \\
\text { the Estimate }\end{array}$ & Durbin-Watson \\
\hline 1 &, $516^{\mathrm{a}}$ &, 266 &, 237 &, 96914 & 2,113
\end{tabular}

a. Predictors: (Constant), ln_der, ln_csr, ln_size

b. Dependent Variable: $\ln \_$per

Sumber : data sekunder diolah.

Berdasarkan tabel di atas nilai Durbin Watson sebesar 2,113, pembanding menggunakan nilai signifikansi 5\%, jumlah sampel 84 (n), dan jumlah variabel independen $1(\mathrm{k}=1)$, maka di tabel Durbin Watson akan didapat nilai du sebesar 1,6212. Karena nilai DW 2,113 lebih besar dari batas atas (du) 1,6212 dan kurang dari $4-1,6212$ (2,3788), maka dapat disimpulkan bahwa tidak terdapat autokorelasi.

\section{Uji Multikolonieritas}

Tabel 5. Uji Multikolonieritas

Coefficients $^{\mathrm{a}}$

\begin{tabular}{|c|c|c|c|c|c|c|c|}
\hline \multirow[b]{2}{*}{ Model } & \multicolumn{2}{|c|}{$\begin{array}{c}\text { Unstandardized } \\
\text { Coefficients } \\
\end{array}$} & \multirow{2}{*}{$\begin{array}{c}\text { Standardized } \\
\text { Coefficients } \\
\text { Beta } \\
\end{array}$} & \multirow[b]{2}{*}{$\mathbf{t}$} & \multirow[b]{2}{*}{ Sig. } & \multicolumn{2}{|c|}{$\begin{array}{l}\text { Collinearity } \\
\text { Statistics }\end{array}$} \\
\hline & B & Std. Error & & & & Tolerance & VIF \\
\hline 1 (Constant) & $-3,208$ & 1,811 & & $-1,772$ &, 081 & & \\
\hline ln_csr & ,637 & , 163 & ,427 & 3,901 & , 000 & ,827 & 1,209 \\
\hline ln_size & 2,142 & ,622 & ,412 & 3,444 & ,001 & 693 & 1,444 \\
\hline ln_der &,- 566 & , 145 &,- 431 & $-3,911$ & , 000 & ,816 & 1,226 \\
\hline
\end{tabular}

a. Dependent Variable: 1 n_per

Sumber : data sekunder diolah

Melihat hasil tabel 5 di atas dapat dilihat bahwa hasil perhitungan Tolerance tidak ada variabel yang memiliki nilai Tolerance kurang dari 0,10 dengan nilai Tolerance masing-masing variabel independen bernilai CSR sebesar 0,827, Ukuran Perusahaan sebesar 0,693, dan DER sebesar 0,816. Sementara itu hasil perhitungan nilai Variance Inflation Factor (VIF) juga menunjukkan hal serupa yaitu tidak adanya nilai VIF dari variabel independen yang memiliki nilai VIF lebih dari 10 dengan nilai VIF masing-masing variabel independen bernilai CSR sebesar 1,209, Ukuran perusahaan sebesar 1,444, dan DER sebesar 1,226. Merujuk hasil perhitungan nilai Tolerance dan VIF dapat disimpulkan bahwa tidak ada multikolonieritas antar variabel independen dalam model regresi. 


\section{Uji Heteroskadisitas}

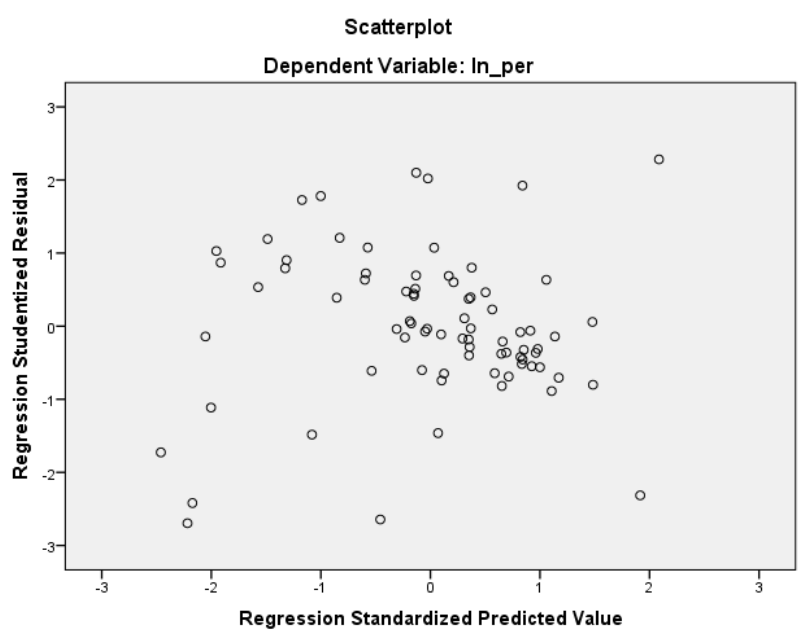

Gambar 3. Uji Heteroskadisitas

Sumber : data sekunder diolah

Berdasarkan dari grafik scatterplot di atas terlihat bahwa titik-titik menyebar di atas dan di bawah angka nol pada sumbu $\mathrm{Y}$, hal ini mengindikasikan bahwa tidak terdapat gangguan heteroskedastisitas pada model regresi.

\section{Hasil Pengolahan Data}

Hasil analisis pengaruh langsung CSR, GCG, Size dan DER terhadap Nilai Perusahaan

Tabel 6. PER $=\alpha+\beta 1$ CSR $+\beta 2$ GCG $+\beta 3$ Size $+\beta 4$ DER + e (Persamaan I)

Coefficients $^{\mathrm{a}}$

\begin{tabular}{|c|c|c|c|c|c|c|}
\hline \multirow{2}{*}{\multicolumn{2}{|c|}{ Model }} & \multicolumn{2}{|c|}{$\begin{array}{c}\text { Unstandardized } \\
\text { Coefficients } \\
\end{array}$} & \multirow{2}{*}{$\begin{array}{c}\text { Standardized } \\
\text { Coefficients }\end{array}$} & \multirow[b]{2}{*}{$\mathbf{t}$} & \multirow[b]{2}{*}{ Sig. } \\
\hline & & B & Std. Error & & & \\
\hline \multirow[t]{5}{*}{1} & (Constant) & $-16,237$ & 5,693 & & $-2,852$ & ,006 \\
\hline & ln_csr &, 500 & , 168 & ,335 & 2,972 & ,004 \\
\hline & ln_gcg & 3,025 & 1,257 & ,248 & 2,406 & ,019 \\
\hline & ln_size & 2,000 & ,606 & ,385 & 3,302 & ,001 \\
\hline & ln_der &,- 580 & , 140 &,- 441 & $-4,129$ & ,000 \\
\hline
\end{tabular}

a. Dependent Variable: $\ln \_$per

Ket. Variabel :

$$
\begin{array}{ll}
\text { PER } & =\text { Nilai Perusahaan } \\
\text { CSR } & =\text { Corporate Social Responsibility } \\
\text { GCG } & =\text { Good Corporate Governance } \\
\text { SIZE } & =\text { ukuran perusahaan } \\
\text { DER } & =\text { Debt to Equity Ratio (leverage) }
\end{array}
$$

Sumber : data sekunder diolah

\section{H1 : CSR berpengaruh positif signifikan terhadap nilai perusahaan}

Hipotesis penelitian di atas menduga CSR berpengaruh positif signifikan terhadap nilai perusahaan. Hipotesis penelitian ini menguji signifikansi koefisien $\beta 1$ secara statistik signifikansinya 
lebih kecil dari 0,05 dan memiliki nilai koefisien regresi positif, maka terdapat bukti empiris yang mendukung H1. Hasil regresi untuk menguji $\mathrm{H} 1$ yang disajikan pada tabel 7 menunjukkan bahwa koefisien $\beta 1$ bernilai 0,500 dengan signifikansi 0,004 $(<0,05)$. Hasil penelitian ini menunjukkan bahwa terdapat bukti empiris untuk menerima hipotesis 1. Dengan demikian $\mathrm{H} 1$ yang menyatakan bahwa CSR berpengaruh positif signifikan terhadap nilai perusahaan didukung oleh data empiris penelitian.

\begin{tabular}{|c|c|c|c|c|c|c|}
\hline \multirow{2}{*}{\multicolumn{2}{|c|}{ Model }} & \multicolumn{2}{|c|}{$\begin{array}{c}\text { Unstandardized } \\
\text { Coefficients } \\
\end{array}$} & \multirow{2}{*}{ 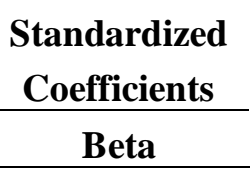 } & \multirow[b]{2}{*}{$\mathbf{t}$} & \multirow[b]{2}{*}{ Sig. } \\
\hline & & B & Std. Error & & & \\
\hline \multirow[t]{6}{*}{1} & (Constant) & 8,918 & 12,997 & & ,686 & ,495 \\
\hline & ln_csr & 20,763 & 9,466 & 13,914 & 2,194 & ,032 \\
\hline & ln_gcg & $-2,904$ & 3,029 &,- 238 &,- 959 & ,341 \\
\hline & csr_GCG & $-4,596$ & 2,146 & $-13,404$ & $-2,141$ & ,036 \\
\hline & ln_size & 2,358 & ,615 & ,453 & 3,837 & ,000 \\
\hline & ln_der &,- 616 & , 138 &,- 469 & $-4,461$ & ,000 \\
\hline
\end{tabular}

a. Dependent Variable: ln_per

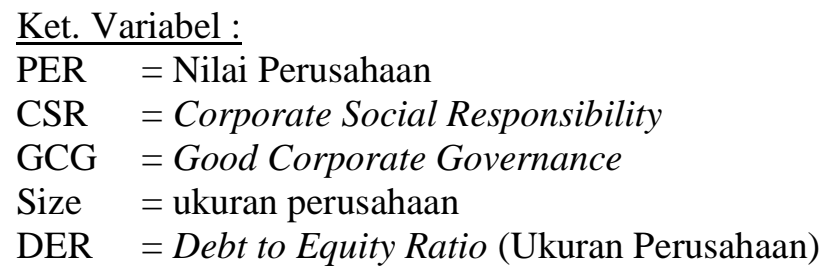

Sumber : data sekunder diolah

\section{H2 : Good Corporate Governance akan memperlemah hubungan antara Corporate Social Responsibility dengan nilai perusahaan.}

Pengujian ini bertujuan menguji peran moderasi GCG pada pengaruh CSR terhadap nilai perusahaan. Hipotesis penelitian ini menguji signifikansi koefisien $\beta 3$ dengan tingkat signifikansi $5 \%$. Apabila $\beta 3$ secara statistik signifikansinya lebih kecil dari 0,05 dan memiliki nilai koefisien regresi positif, maka terdapat bukti empiris yang mendukung $\mathrm{H} 2$. Hasil regresi untuk menguji $\mathrm{H} 2$ yang disajikan pada tabel 4.8 menunjukkan bahwa koefisien $\beta 3$ bernilai $-4,596$ dengan signifikansi sebesar 0,036 $(<0,05)$. Hasil penelitian ini menunjukkan bahwa terdapat bukti empiris untuk menerima hipotesis 2. Hal ini menunjukkan bahwa peningkatan GCG akan cenderung memperlemah hubungan antara CSR terhadap nilai perusahaan. Jadi, dapat disimpulkan bahwa GCG memperlemah hubungan CSR terhadap nilai perusahaan atau dengan kata lain CSR dapat menurunkan nilai perusahaan pada saat GCG tinggi.

Dengan demikian H2 menyatakan bahwa GCG tidak mampu memperkuat pengaruh CSR terhadap nilai perusahaan didukung oleh data empiris penelitian. 


\section{Uji Hipotesis}

Tabel 8. Uji Koefisien Determinasi $\left(\mathrm{R}^{2}\right)$

Hasil Uji Koefisien Determinasi $\left(\mathbf{R}^{2}\right)$

Model Summary ${ }^{b}$

\begin{tabular}{|c|c|c|c|c|c|}
\hline Model & $\mathbf{R}$ & R Square & $\begin{array}{c}\text { Adjusted R } \\
\text { Square } \\
\end{array}$ & $\begin{array}{c}\text { Std. Error of the } \\
\text { Estimate }\end{array}$ & Durbin-Watson \\
\hline 1 &, $566^{\mathrm{a}}$ & ,320 & ,283 & 93922, & 2,208 \\
\hline
\end{tabular}

a. Predictors: (Constant), ln_der, ln_csr, ln_gcg, ln_size

b. Dependent Variable: ln_per

Sumber : data sekunder diolah

Berdasarkan tabel 8 di atas menunjukkan bahwa nilai (Adjusted $R$ Square) adalah sebesar 0,283 atau $28,3 \%$. Hal ini menunjukkan bahwa nilai perusahaan dapat dijelaskan sebesar $28,3 \%$ oleh variabel yaitu CSR, GCG, Ukuran perusahaan dan leverage. Sedangkan 8,1\% variasi nilai perusahaan dijelaskan oleh variabel-variabel di luar variabel independen penelitian ini. Sedangkan Standar Error of the Estimate (SEE) sebesar 0,93922. Makin kecil Standar Error of the Estimate (SEE) akan membuat model regresi semakin tepat dalam memprediksi variabel dependen yaitu nilai perusahaan dengan variabel independennya.

Uji Parsial (Uji t)

Tabel 9. Uji Parsial (Uji t)

Coefficients $^{\mathbf{a}}$

\begin{tabular}{rlrrrrrr}
\hline & & \multicolumn{2}{c}{$\begin{array}{c}\text { Unstandardized } \\
\text { Coefficients }\end{array}$} & \multicolumn{2}{c}{$\begin{array}{c}\text { Standardized } \\
\text { Coefficients }\end{array}$} & & \\
\cline { 3 - 5 } Model & & \multicolumn{1}{c}{ B } & Std. Error & Beta & \multicolumn{1}{c}{ t } & \multicolumn{1}{c}{ Sig. } \\
\cline { 3 - 4 } 1 & (Constant) & $-16,237$ & 5,693 & & $-2,852$ &, 006 \\
& ln_csr &, 500 &, 168 &, 335 & 2,972 &, 004 \\
& ln_gcg & 3,025 & 1,257 &, 248 & 2,406 &, 019 \\
& ln_size & 2,000 &, 606 &, 385 & 3,302 &, 001 \\
& ln_der &,- 580 &, 140 &,- 441 & $-4,129$ &, 000 \\
\hline
\end{tabular}

a. Dependent Variable: ln_per

Sumber : data sekunder diolah

Berdasarkan tabel 9 di atas menunjukkan pengujian yang dilakukan untuk memperoleh pengaruh yang signifikan dari keempat variabel terhadap nilai perusahaan adalah sebagai berikut :

a. Berdasarkan tabel 9 koefisien regresi CSR sebesar 0,500. Hal ini menunjukkan bahwa CSR mempunyai pengaruh yang positif terhadap nilai perusahaan. Nilai probabilitas menunjukkan lebih kecil dari 0,05 yaitu sebesar 0,004, yang artinya bahwa variabel CSR secara parsial mempunyai pengaruh signifikan terhadap nilai perusahaan.

b. Berdasarkan tabel 9 koefisien regresi GCG sebesar 3,025. Hal ini menunjukkan bahwa GCG mempunyai pengaruh positif terhadap nilai perusahaan. Nilai probabilitas menunjukkan lebih kecil dari 0,05 yaitu sebesar 0,019, yang artinya bahwa variabel GCG secara parsial mempunyai pengaruh signifikan terhadap nilai perusahaan.

c. Berdasarkan tabel 9 koefisien regresi ukuran perusahaan sebesar 2,000. Hal ini menunjukkan bahwa ukuran perusahaan mempunyai pengaruh yang positif terhadap nilai perusahaan. Nilai probabilitas menunjukkan lebih kecil dari 0,05 yaitu sebesar 0,001 , yang artinya bahwa variabel ukuran perusahaan secara parsial mempunyai pengaruh signifikan terhadap nilai perusahaan. 
d. Berdasarkan tabel 9 koefisien regresi leverage sebesar -0,580. Hal ini menunjukkan bahwa leverage mempunyai pengaruh negatif terhadap nilai perusahaan. Nilai probabilitas menunjukkan lebih kecil dari 0,05 yaitu 0,000, yang artinya bahwa variabel ukuran perusahaan secara parsial mempunyai pengaruh signifikan terhadap nilai perusahaan.

Uji Simultan (Uji F)

Tabel 10. Uji Simultan (Uji F)

ANOVA $^{\mathrm{a}}$

\begin{tabular}{llrrrrr}
\hline \multicolumn{1}{l}{} & \multicolumn{2}{c}{ Sum of } & & & & \\
\multicolumn{1}{l}{ Model } & Squares & Df & Mean Square & \multicolumn{1}{c}{ F } & \multicolumn{1}{c}{ Sig. } \\
\hline 1 & Regression & 30,351 & 4 & 7,588 & 8,601 &, $000^{\mathrm{b}}$ \\
& Residual & 64,396 & 73 &, 882 & & \\
& Total & 94,747 & 77 & & & \\
\hline
\end{tabular}

a. Dependent Variable: $1 n \_$per

c. Predictors: (Constant), ln_der, ln_csr, ln_gcg, ln_size

Sumber : data sekunder diolah

Berdasarkan tabel 10 di atas didapatkan nilai $\mathrm{F}$ hitung sebesar 8,601 dengan taraf signifikansi 0,000. Karena probabilitasnya jauh lebih kecil dari 0,05 maka dapat dikatakan bahwa leverage, CSR, GCG dan ukuran perusahaan secara bersama-sama berpengaruh signifikansi terhadap nilai perusahaan.

\section{KESIMPULAN}

Berdasarkan hasil penelitian yang dilakukan oleh penulis melalui analisis data statistik dan pembahasan, maka dapat ditarik kesimpulan sebagai berikut :

1. Penelitian ini membuktikan CSR berpengaruh positif signifikan terhadap nilai perusahaan. Semakin baik penerapan CSR oleh perusahaan maka nilai perusahaan akan semakin meningkat. Hal ini diharapkan dapat meningkatkan kesadaran perusahaan untuk melakukan aktivitas CSR dan pengungkapannya. Sehingga dalam jangka panjang perusahaan dapat menikmati kinerja pasar yang baik yang nantinya akan dinikmati oleh masyarakat secara umum.

2. Penelitian ini membuktikan GCG tidak mampu memperkuat atau dengan kata lain memperlemah pengaruh CSR terhadap nilai perusahaan. nilai yang tinggi dalam pemeringkatan CGPI tidak menjamin bahwa investor akan merespon positif terhadap peristiwa tersebut. Selain itu, pemeringkatan CGPI di Indonesia masih bersifat voluntary (sukarela) dan tidak diwajibkan sehingga perusahaan yang ikut dalam pemeringkatan CGPI setiap tahunnya tidak sama dan hanya sebagian kecil dari keseluruhan perusahaan (hanya beberapa perusahaan yang ikut berturut-turut setiap tahunnya).

\section{DAFTAR PUSTAKA}

Armi, Ni Ketut Suransi, Alamsyah, 2016. Pengaruh GCG Terhadap Nilai Perusahaan Dengan Profitabilitas Sebagai Variabel Pemoderasi. Jurnal Infestasi Universitas Mataram.

Auliyah, Ronny dan Agus Salim, 2017. Pengaruh kinerja keuangan terhadap nilai perusahaan dengan pengungkapan CSR dan GCG sebagai variabel moderating. E-jurnal riset manajemen Universitas Islam Malang.

Ayu Indriani. 2018. Pengaruh Indeks Corporate Governance, leverage, profitabilitas dan ukuran perusahaan terhadap nilai perusahaan. Skripsi Universitas Diponegoro Semarang. 
Bayu Suryonugroho. 2016. Pengaruh Corporate Social Responsibility (CSR) terhadap Nilai perusahaan dengan kepemilikan institusional, kepemilikan manajemen dan ukuran perusahaan sebagai variabel moderating (studi empiris pada perusahaan pemenang ISRA yang terdaftar di bursa efek Indonesia 2009-2012). Skripsi, Universitas Negeri Yogyakarta.

Dewi, dan Moch Imron. 2013. Pengaruh Corporate Social Responsibiliy dan Good Corporate Governance terhadap Nilai Perusahaan dengan Ukuran Perusahaan Sebagai Variabel Pemoderasi (studi kasus pada perusahaan manufaktur yang terdaftar di BEI). Jurnal .

Dewi Winarti, 2012. Pengaruh Corporate Social responsibility dan Good Corporate Governance Terhadap Nilai Perusahaan dengan Ukuran Perusahaan Sebagai Variabel Moderasi (Studi KasusPada Perusahaan Manufaktur yang terdaftar di BEI). Jurnal.

Dwi Santoso, 2018. Pengaruh struktur modal dan keputusan investasi terhadap nilai perusahaan dengan profitabilitas sebagai variabel moderasi (studi empiris pada perusahaan sektor non keuangan indeks LQ45 periode 2013-2017). Skripsi, Institute Teknologi dan Bisnis Ahmad Dahlan, Jakarta.

Dyah Ardana Riswari, 2012. Pengaruh Corporate Social Responsibility Terhadap Nilai Perusahaan dengan Corporate Governance Sebagai Variabel Moderating (Studi pada perusahaan publik non finansial yang tercatat di Bursa Efek Indonesia Tahun 2008-2009). Jurnal.

Edwin Wijaya. 2017. Pengaruh Good Corporate Governance dan pengungkapan Corporate Social Responsibility terhadap nilai perusahaan. Skripsi, Universitas Lampung, Lampung.

Effendi, Muh. Arief. 2016. The Power of Good Corporate Governance teori dan Implementasi. Edisi 2. Jakarta : Salemba Empat.

Faisal, Suroto,2019. Pengaruh Good Corporate Governance dan Firm Size terhadap profitabilitas.(studi Empiris pada perusahaan Non Keuangan Indeks LQ45 yang terdaftar di BEI tahun 2013-2017). Skripsi, Institute Teknologi dan Bisnis Ahmad Dahlan, Jakarta.

Ghozali, Imam \& Chariri, Anis. 2014. Teori Akuntansi Internasional Financial Reporting System (IFRS). Semarang: Badan Penerbit Universitas Diponegoro

Ghozali, Imam. 2016. Aplikasi analisis Multivariete dengan program IBM SPSS 23 (edisi 8). Cetakan ke VIII. Semarang : Badan Penerbit Universitas Diponegoro.

Gusti Ayu, Gede Juliarsa, Maria M. 2013. Pengaruh Pengungkapan CSR terhadap nilai perusahaan dengan profitabilitas sebagai variabel pemoderasi. E-Jurnal Akuntansi Universitas Udayana.

Hamdani, 2016. Good Corporate Governance: Tinjauan Etika dalam Praktik Bisnis.Edisi 1.

I Putu Indra Wijaya dan Ni Gusti Putu Wirawati, 2019. Good Corporate Governance Pemoderasi Pengaruh Profitabilitas dan Corporate Social Responsibility Pada Nilai Perusahan. E-Jurnal Akuntansi Universitas Udayana Bali.

Junda Muhammad, 2018. Pengaruh Good Corporate Governance dan Corporate Social Responsibility Terhadap Nilai Perusahaan. Skripsi Universitas Islam Negeri Yogyakarta.

Katiya, D. Agus Harjito, 2011. Pengaruh Corporate Social responsibility Terhadap Nilai Perusahaan Dengan Good Corporate Governance Sebagai Pemoderasi. Jurnal Siasat Bisnis Universitas Islam Indonesia. 
Maria dan Gerianta, 2013. Pengaruh Kinerja Keuangan Terhadap Nilai Perusahaan Dengan Pemoderasi Good Corporate Governance dan Corporate Social Responsibility. E-Jurnal Akuntansi Universitas Udayana Bali.

Maureen dan Indah. 2017. Pengaruh Good Corporate Governance dan Corporate Social Responsibility terhadap nilai perusahaan. Konferensi ilmiah akuntansi IV Universitas Pancasila.

Nofiani, Fifi dan Nurmayanti, Poppy. 2010. Pengaruh Penerapan Corporate Governance Terhadap Kinerja Keuangan Perusahaan. Pekbis Jurnal. Volume 2 Nomor 1. Noviawan, Ridho Alief d.

Reny Dyah Retno dan Denies Priantinah, 2012. Pengaruh Good Corporate Governance dan Pengungkapan Corporate Social Responsibility Terhadap Nilai Perusahaan (Studi Empiris Pada Perusahaan Yang Terdaftar Di Bursa Efek Indonesia Periode 2007-2010). Jurnal Nominal Universitas Negeri Yogyakarta.

Setianingrum, Wahyuning Ambar. 2015. Pengaruh CSR terhadap nilai perusahaan dengan profitabilitas sebagai variabel moderasi. Semarang: Universitas negeri Semarang.

Sri Mulyani, 2019. Pengaruh Kepemilikan Manajerial, Ukuran Perusahaan, dan Debt To Total Assets Ratio (DAR) Terhadap Nilai Perusahaan pada perusahaan otomotif dan Komponen di BEI Tahun 2010-2018. Sksripsi Institute Teknologi dan Bisnis Ahmad Dahlan Jakarta.

Stacia, Evelyn dan Juniarti. 2015. Pengaruh Pengungkapan CSR Terhadap Nilai Perusahaan di Sektor Pertambangan. Surabaya: Universitas Kristen Petra.

Tikka. 2019. Laporan Good Corporate Governance (https://tikkastory.blogspot.com/2019/07/laporan- corporate-governance-perceprion.html di akses 10 Oktober) Tria, Nila, Ferina, 2018. Pengaruh Good Corporate Governance Terhadap Nilai Perusahaan (studi pada perusahaan industry sub sektor logam dan sejenisnya yang terdaftar di BEI periode 2012-2016). Jurnal Administrasi Bisnis Universitas Brawijaya Malang.

Winda Heldayati Rahajeng Putri. 2014. Pengaruh Corporate Social Responsibility terhadap nilai perusahaan dan Good Corporate Governance sebagai pemoderasi pada industri makanan dan minuman yang terdaftar di BEI periode : 2010-2013. Artikel Ilmiah Sekolah Tinggi Ilmu Ekonomi Perbanas Surabaya.

Yulia Firda, 2019. Pengaruh Corporate Social Responsibility Discloure, Firm Size dan Leverage Terhadap Nilai Perusahaan Dengan Profitabilitas Sebagai Variabel Moderating (Studi Empiris Pada Perusahaan Pertambangan Yang Terdaftar di BEI Tahun 2014-2018). Skripsi Institute Teknologi dan Bisnis Ahmad Dahlan Jakarta.

www.idx.co.id

www.cnnindonesia.com

www.cnbcindonesia.com 